Published in: International Tax and Public Finance, 2022, Article

\title{
Media Bias and Tax Compliance: Experimental Evidence
}




\section{Media Bias and Tax Compliance: Experimental Evidence}

\section{Abstract}

We study the impact of media bias on tax compliance. Through a framed laboratory experiment, we assess how the exposure to biased news about government action affects compliance in a repeated taxation game. Subjects treated with positive news are significantly more compliant than the control group. The exposure to negative news, instead, does not prompt any significant reaction in respect to the neutral condition, suggesting that participants perceive the media negativity bias in the selection and tonality of news as the norm rather than the exception. Overall, our results suggest that biased news act as a constant source of psychological priming and play a vital role in taxpayers' compliance decisions.

\footnotetext{
Masaryk University

Faculty of Economics and Administration

Authors:

Miloš Fišar (ORCID: 0000-0003-4153-3500) / Vienna University of Economics and Business \& Masaryk University

Tommaso Reggiani (ORCID: 0000-0002-3134-1049) / Cardiff University, Masaryk University \& IZA

Fabio Sabatini (ORCID: 0000-0002-1228-3322) / Sapienza University of Rome \& IZA

Jiří Špalek (ORCID: 0000-0001-5832-4946) / Masaryk University
}

Contact: tommaso.reggiani@econ.muni.cz

Creation date: $2020-01$

Revision date: 2023-01

Keywords: Tax compliance, media bias, taxation game, laboratory experiment.

JEL classification: C91, D70, H26, H31

\section{Citation:}

Fišar, M., Reggiani, T., Sabatini, F., Špalek, J. (2020). Media Bias and Tax Compliance:

Experimental Evidence. MUNI ECON Working Paper n. 2020-01. Brno: Masaryk University.

https://doi.org/10.5817/WP_MUNI_ECON_2020-01 


\title{
Media bias and tax compliance: Experimental evidence*
}

\author{
Miloš Fišar; Tommaso Reggianił Fabio Sabatinił Jiří Špalek $\mathbb{I}$
}

January 21, 2020

\begin{abstract}
We study the impact of media bias on tax compliance. Through a framed laboratory experiment, we assess how the exposure to biased news about government action affects compliance in a repeated taxation game. Subjects treated with positive news are significantly more compliant than the control group. The exposure to negative news, instead, does not prompt any significant reaction in respect to the neutral condition, suggesting that participants perceive the media negativity bias in the selection and tonality of news as the norm rather than the exception. Overall, our results suggest that biased news act as a constant source of psychological priming and play a vital role in taxpayers' compliance decisions.
\end{abstract}

Keywords: tax compliance, media bias, taxation game, laboratory experiment.

JEL Classification: C91, D70, H26, H31.

${ }^{*}$ We thank James Alm, Lubomír Cingl, Davide Fiaschi, Caterina Giannetti, Alice Guerra, Antoine Malezieux, and Carla Marchese for helpful comments and suggestions. Otto Eibl, Jozef Zagrapan, and Zuzana Špačková provided precious feedback for the development of the research design. The paper also benefited from comments by participants at the 2018 European Public Choice Society Conference in Rome, the 2019 Society for the Advancement of Behavioral Economics Conference in Dublin, and at seminars at Masaryk University, University of Economics in Prague, University of Pisa, Technical University in Košice, Sapienza University of Rome, and University of Regensburg. Financial support from the Czech Science Foundation (project no. GA17-00496S) is gratefully acknowledged. Usual caveats apply.

${ }^{\dagger}$ Vienna University of Economics and Business, Competence Center for Experimental Research, Vienna, Austria. Masaryk University, MUEEL lab - Department of Public Economics, Brno, Czech Republic. Email: milos.fisar@econ.muni.cz.

${ }^{\ddagger}$ Corresponding author. Cardiff University, Cardiff Business School, Cardiff, United Kingdom. Masaryk University, MUEEL lab - Department of Public Economics, Brno, Czech Republic. IZA, Bonn, Germany. Email: tommaso.reggiani@econ.muni.cz.

\$Sapienza University of Rome, Department of Economics and Law, Rome, Italy. IZA, Bonn, Germany. Email: fabio.sabatini@uniroma1.it.

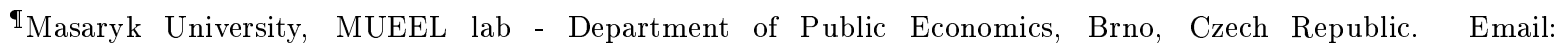
jiri.spalek@econ.muni.cz. 


\section{Introduction}

Economists have traditionally modeled tax compliance as the outcome of a rational choice between risky assets in a portfolio (Becker, 1968; Allingham and Sandmmo, 1992). This approach does not fully explain the compliance behavior of individuals, as moral and social dynamics also drive individual reporting decisions (Andreoni et al., 1998). Previous research suggests that the satisfaction taxpayers have with government action is a critical driver of their propensity to comply. If citizens believe that the government does not spend their taxes well, they may want to reciprocate by refusing to pay their full tax liability (Spicer and Lundstedt, 1976). If, instead, the belief prevails that institutions use taxes to fund public goods and services adequately, taxpayers will be more willing to comply (Alm et al., 1993). Even when they do not receive a full public good equivalent of their payments, citizens may be intrinsically motivated to honestly declare their income as if a "psychological contract" with tax authorities was in force (Frey and Feld, 2002; 2004). According to Feld and Frey (2007), such a contract holds as far as citizens perceive the political process as fair and the policy outcomes as legitimate, resulting in a stronger willingness to contribute to the welfare of the community.

These perspectives imply a vital role for information about government action and the fairness of the political process. The media's coverage of economic and policy issues, however, is far from being balanced. Mass media tend to overreport negative news as they generate stronger psychophysiological reactions in the audience (Soroka et al., 2019), and they better fit the public's preference for negative contents (Agridas 2015). The negativity bias has proved particularly pronounced in the presentation of political (Cappella and Jamieson, 1997; Kepplinger et al., 2012; Le Moglie and Turati, 2019) and economic news (Garz 2014; Soroka et al., 2018). Given the role of information in shaping the public's opinion about public institutions, research on tax compliance should address the impact of the media negativity bias. However, empirically studying how the media affect citizens' willingness to pay their taxes is challenging in many respects. Existing surveys do not provide information about the possible bias of the news consumed by the public, and the use of survey data entails endogenous sample selection and treatment assignment that prevent ascertaining causality.

To address these issues, we design a framed laboratory experiment that allows us to analyze how the exposure to biased news affects compliance in a repeated taxation game. Experimental manipulations consist of news tickers reporting top stories about public finance and policy issues 
that run on subjects' screens during the game. Employing a between-subjects design, we contrast tax compliance outcomes under three different conditions: negative, positive, and neutral news provision. The negative treatment reflects the media negativity bias that is the status quo in the supply of news about public finance and policy issues (Soroka et al., 2018; Soroka et al., 2019). Compared to the neutral treatment, the negative news condition does not affect tax compliance, confirming that participants perceive the media negativity bias as the norm rather than the exception (Cappella and Jamieson, 1997; Kepplinger et al., 2012; Garz, 2014; Soroka et al., 2019; Elejalde et al., 2018). As the selection and tonality of news deviate from the status quo resulting in positive content, participants become significantly more compliant than the control group. The effect is economically sizable: subjects treated with good news reported a compliance rate of 23 percentage points higher than those exposed to negative or neutral news. Overall, our results reveal that how the media present public finance and policy issues is a crucial determinant of tax compliance, suggesting that biased news act as a constant source of psychological priming that may prevent the public sector from fully exploiting its tax revenue potential.

Our paper bridges two strands of literature. The first comprises the economics of tax compliance, which has been approached from many perspectives (see Andreoni et al., 1998, and Alm, 2019, for a review). We focus on the moral and social perspective on taxpayers' behavior, which has linked compliance to the efficiency and fairness of public institutions (Spicer and Lundstedt, 1976; Tyler, 1990; Smith, 1992; Alm et al., 1993; Frey et al., 2004; Feld and Frey, 2007; Hartner et al., 2008; Murphy and Tyler, 2008; van Dijke and Verboon, 2010; Kogler et al., 2016; Gobena and van Dijke, 2017; Koessler et al., 2019). These studies implicitly assume a critical role for information. We clarify this role and add to the literature by showing the compliance implications of biased information about government action and public finance issues. More in general, our findings improve the understanding of the psychological and social drivers of compliance, also including peer effects (Alm et al., 2017b), cultural traits (Torgler, 2006; Alm et al., 2017a), trust in institutions (van Dijke and Verboon, 2010), corruption (Alm et al., 2016), fairness concerns (Alesina and Angeletos 2005; Gualtieri et al., 2019; Sabatini et al., 2020), and intrinsic motivations (Luttmer and Singhal, 2011; 2014; Calvet Christian and Alm, 2014; Dwenger et al. 2016; Cerqueti et al., 2019).

The second strand of literature studies how media bias affects voting behavior (Della Vigna and Kaplan 2007; Chiang and Knight 2011), news contents consumption (Durante and Knight 2012), civic-mindedness (Durante et al. 2019), crime perceptions (Mastrorocco and Minale 2018; Benesch 
et al., 2019), and consumption behavior (Nguyen and Claus 2013), just to name a few. We contribute to this field by revealing a so far unexplored outcome of media bias. Our experimental approach also adds to the communication literature that has first detected the existence of the media negativity bias (Cappella and Jamieson, 1997; Garz 2014; Trussler and Soroka 2014; Soroka et al. 2018; Soroka et al. 2019), by showing that the systematic tendency of the media to focus on negative news entails hidden social costs connected to the government's inability to meet its revenue objectives.

The rest of the paper proceeds as follows. Section 2 describes our experimental design and procedures. Section 3 presents our results. We discuss our findings and their possible policy implications in Section 4 and conclude in Section 5.

\section{Experimental design}

To circumvent the selection and endogeneity problems arising in the analysis of naturally occurring data, we designed a framed laboratory experiment (Harrison and List, 2004) where we targeted three distinct randomly determined groups of participants with two main treatments respectively based on the exposure to negative $\left(T_{N E G}\right)$ and positive $\left(T_{P O S}\right)$ media bias. A third control group received a neutral $\left(T_{N E U}\right)$ treatment characterized by the absence of any salient bias. Experimental manipulations consisted of news tickers reporting top stories about public finance and policy issues that ran on subjects' screens during a repeated taxation game(Alm et al., 2015; Alm et al., 2019).

As empirical research on tax evasion has shown that compliance decisions might also depend on the source of income (Clark, 2002; Gërxhani and Schram, 2006; Durham et al., 2014), we made individuals earn their endowments under two different configurations for each treatment. In the first configuration, participants earned income by working on a structured series of conventional realeffort tasks $\left(C_{R E}\right)$ and were rewarded based on their performance. ${ }^{1}$ We calibrated the piece rates in order to generate a framed endowment $Y \in(8,500 ; 55,000)$ ECU compatible with the nominal distribution of income in the Czech Republic. ${ }^{2}$ In the second configuration, subjects exogenously received an endowment in the form of windfall money $\left(C_{W F}\right)$ drawn for the actual endowment distribution generated in the real-effort sessions. Participants played a conventional taxation game (Malezieux, 2018) in groups of four subjects in a partner-matching protocol. The game was repeated

\footnotetext{
${ }^{1}$ Subjects were asked to work for 2 minutes to each one of following tasks: matrix-counting task (Abeler et al., 2011), anagram task (Charness and Villeval, 2009), adding-to-10 task (Mazar et al., 2008), and a stoop-color test (Scarpina and Tagini, 2017).

${ }^{2}$ The exchange rate was 200 experimental currency units (ECU) for one Czech Crown (CZK), with 5000 ECU $\approx 1$ EURO.
} 
for five rounds. Subjects received information about their earnings at the end of each round. The final payment consisted of the sum of the earnings obtained in the five rounds. Each round of the taxation game was partitioned into three sequential stages. (I) The first stage concerned the individual income generation. (II) In the second stage, we asked participants to self-report their income to establish their tax liability. We then taxed the declared income at a flat rate $t=0.15$ as for the personal income tax rate in the Czech Republic. Tax audits took place between the second and third stages. The probability of receiving an audit was $p=0.05$. Tax authorities imposed to cheaters a fine equal to the unpaid amount multiplied by a penalty $\alpha=10$. (III) In the third stage, participants learned about taxation outcomes and anonymized ${ }^{3}$ audit results. Subjects could also see the amount of taxes overall paid by the group. To model the utility generated by the consumption of the public good funded through the taxation scheme, each participant received a share of the total tax revenue $\beta=0.125$. As a result, the payoff function was:

$$
\pi_{i}(1-p)=y_{i}-t x_{i}+\sum_{i=1}^{4} \beta t x_{i}
$$

for subjects who did not receive the audit, and:

$$
\pi_{i}(p)=y_{i}-t x_{i}+\sum_{i=1}^{4} \beta t x_{i}-\alpha\left(y_{i}-x_{i}\right)
$$

for participants targeted with a tax inspection.

Throughout the three stages of the game, news headlines appeared every six seconds at the bottom of participants' screens. The main treatment manipulation consisted of randomly assigning headlines with a systematically biased tone (positive, negative, and neutral) to each distinct experimental group of subjects. Under the positive treatment, participants regularly saw positive news about the efficient use of the government budget (for example, State Housing Department Fund will provide advantageous loans, or Governmental program supporting science centers and generous grants successful: best minds returning home). In the negative treatment that aimed at reproducing the real-world media negativity bias, subjects saw headlines reporting negative news on the ineffective or inappropriate use of public funds (for example, National debt increased to CZK 1.68 billion, or Low civil servant efficiency decreased the Czech Republic's competitiveness; down to 46th in global ranking). In the neutral treatment (baseline condition), the news reported about public events of

\footnotetext{
${ }^{3}$ See Casal and Mittone (2016) about the role of anonymity in income reporting games.
} 
general interest having very neutral contents (for example, The World Dog Show in Crufts is hosting 28 thousand dogs). Appendix A reports the full list of top headlines in detail.

A focus group of ten Ph.D. students in political sciences (five males, five females) at Masaryk University selected the news headlines and classified their tone. Building on computational linguistics methods (Taboada et al., 2011), we then assessed the sentiment of the different sets of news through the algorithm developed by Repustate.com. The algorithm delivers a rating ranging between -1.00 and -0.51 if the news is negative, -0.50 and 0.50 in the case of neutral news, and between 0.51 and 1.00 for positive news. In our experiment, the average score was -0.75 for the set of news displayed in the negative treatment, 0.01 for the neutral treatment, and 0.87 for the positive treatment.

A total of 240 subjects, recruited via Hroot (Bock et al., 2014), participated in the experiment. After showing up at pre-scheduled session times, subjects were seated at individual cubicles equipped with computers. Seats were randomly assigned. Sessions took place at the Masaryk University Experimental Economics Laboratory (MUEEL) in Brno (Czech Republic). The language of the experiment was Czech. We programmed and implemented the experiment using zTree (Fischbacher, 2007). Sessions lasted about 60 minutes, including a post-experimental questionnaire, and the average payoff was approximately 10 EURO $\left(250 \mathrm{CZK}\right.$, including the show-up fee). ${ }^{4}$ Table 1 reports descriptive information about the composition of the experimental sessions in all their treatmentconfiguration factorial interactions $T_{i}{ }^{*} C_{j}$ (3x2 full-factorial design).

Table 1: Summary: factorial design.

\begin{tabular}{|c|c|c|c|c|}
\hline $\begin{array}{l}\text { Factorial } \\
\text { interaction }\end{array}$ & Subjects & Obs. & $\%$ Males & Age \\
\hline$T_{N E U^{*}} C_{W F}$ & 24 & 120 & 0.50 & $\begin{array}{l}22.12 \\
(2.71)\end{array}$ \\
\hline$T_{N E G}{ }^{*} C_{W F}$ & 40 & 200 & 0.45 & $\begin{array}{l}22.65 \\
(2.02)\end{array}$ \\
\hline$T_{P O S}{ }^{*} C_{W F}$ & 40 & 200 & 0.42 & $\begin{array}{l}22.20 \\
(1.80)\end{array}$ \\
\hline$T_{N E U^{*}} C_{R E}$ & 24 & 120 & 0.46 & $\begin{array}{l}22.45 \\
(1.91)\end{array}$ \\
\hline$T_{N E G}{ }^{*} C_{R E}$ & 44 & 220 & 0.30 & $\begin{array}{l}22.79 \\
(1.15)\end{array}$ \\
\hline$T_{P O S}{ }^{*} C_{R E}$ & 48 & 240 & 0.29 & $\begin{array}{l}22.44 \\
(1.77)\end{array}$ \\
\hline Total & 220 & 1,100 & 0.39 & $\begin{array}{l}22.48 \\
(1.86)\end{array}$ \\
\hline
\end{tabular}

\footnotetext{
${ }^{4}$ In PPP, 1 Euro in the Czech Republic is equivalent to 1.45 Euros in Germany, as reference Euro country.
} 


\section{Results}

In this section, we first report about the balancedness of several sample's dimensions across experimental groups. We then document how the exposure to biased news affects participants' decision to comply in Section 3.2. Section 3.3 presents the results regarding the magnitude of tax evasion. Offering results from additional Double-Hurdle regression models, Section 3.4 blends together adopting an integrated framework - the two sets of results discussed in Sections 3.2 and 3.3 focusing on extensive and intensive tax evasion margins, respectively.

\subsection{Randomization check}

Table 2 reports the mean values and randomization checks ( $p$-values according to Chiapello, 2018) of some conventional individual characteristics elicited with a standard post-experimental questionnaire (gender, age, field of studies, religious and political attitudes, and the individual degree of risk aversion). ${ }^{5}$ Most of these individual characters are uniformly balanced across treatments (neutral, negative, positive) and configurations (real-effort, windfall). In the following parametric analysis (Sections $3.2,3.3,3.4$ ), we will also take into consideration this specific array of covariates in order to control for the few non-perfectly balanced characteristics.

\subsection{Tax compliance rate}

We start by investigating tax compliance along its extensive margin, related to the share of taxpayers who choose to evade under the three experimental treatments (negative, neutral, and positive). We measure compliance as a binary variable having value 1 when participants correctly report their income and 0 when they underreport. In Figure 1, we plot the shares of tax compliers under the three main treatments. While under the neutral and the negative treatments, the share of compliers ranges between 35 and 40 per cent, under the positive treatment, approximately 60 per cent of participants duly reported their actual income. This difference is evocative (Jonckheere-Terpstra

\footnotetext{
${ }^{5}$ We elicit individuals' attitudes towards risk through a conventional incentivized multi-lottery choice task (Attanasi et al., 2018). The index, ranging from 0 to 1, captures the increasing gradients of risk version: 0 indicates risk proneness, 1 maximum risk aversion.
} 


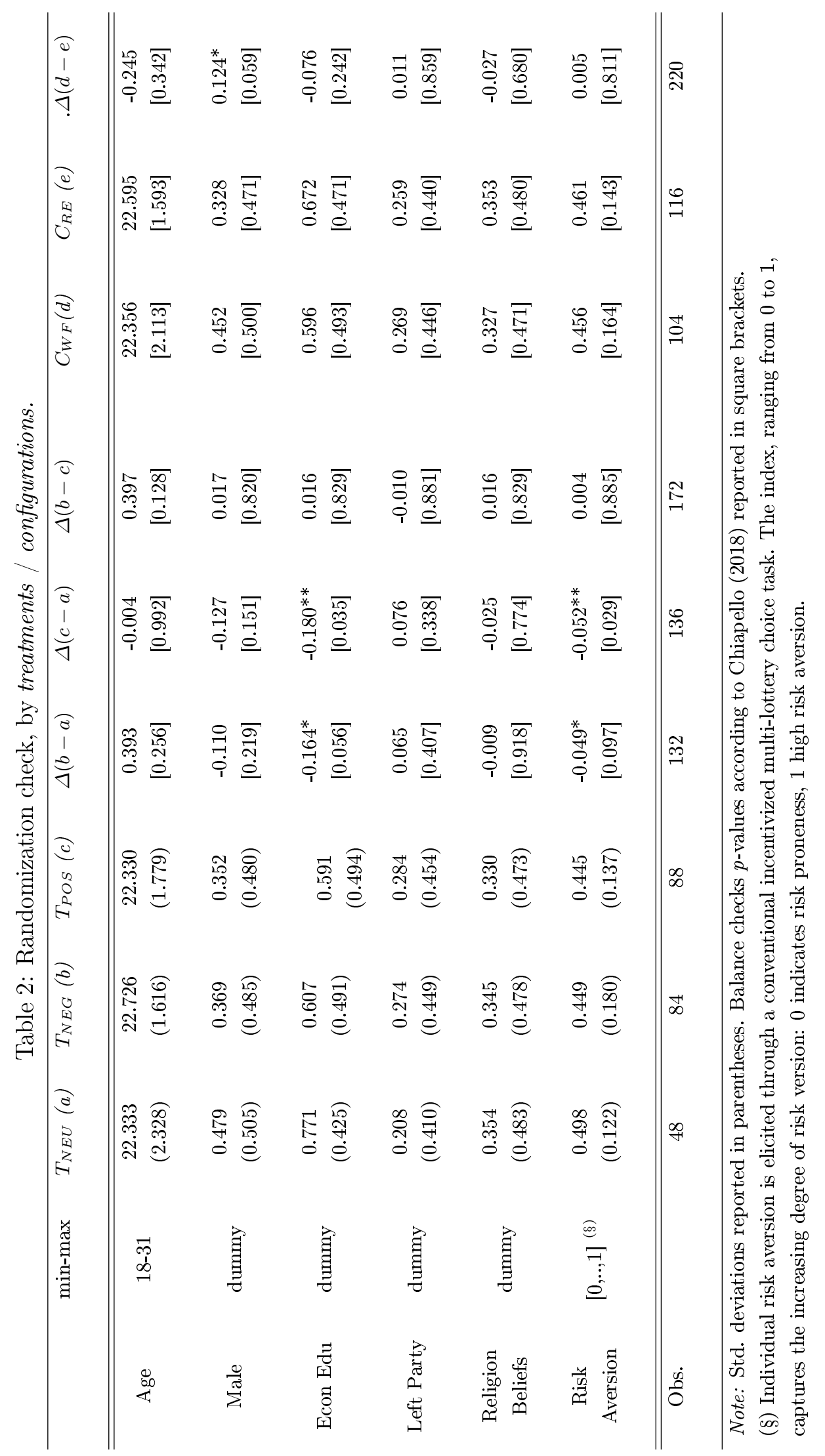


Figure 1: Share of tax compliers, by treatmets

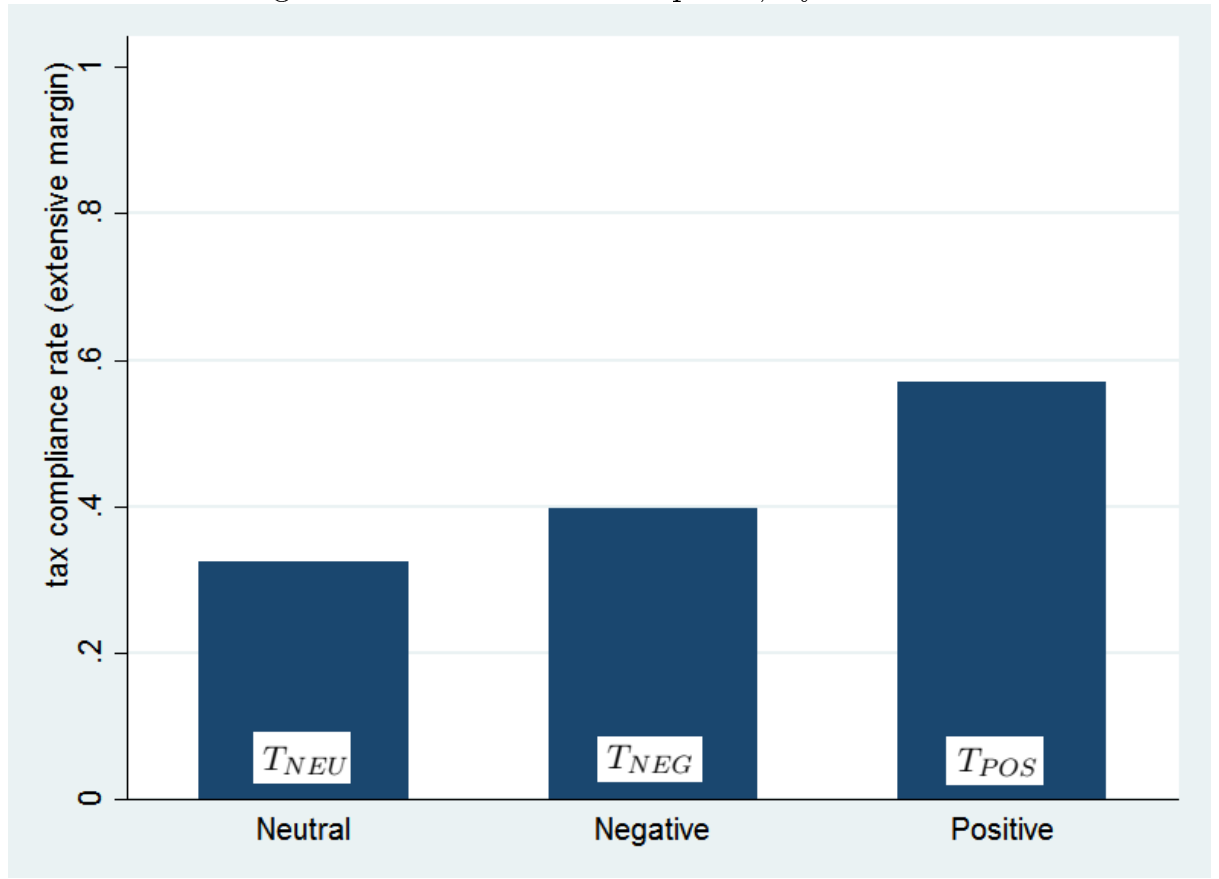

test for ordered alternatives, $p$-value $<0.01$ ) but not fully statistically accurate, as these shares stem from repeated observations at the group and individual level.

To take into account such interdependencies, Table 2 reports a battery of panel estimates from two-way linear probability models with random effects accounting for both potential individual dependencies over rounds and dependency at the group level (Corazzini et al., 2015, 2019).

$$
Y_{i t}=\beta_{0}+\beta_{1} T_{N E G}+\beta_{2} T_{P O S}+\beta_{n}[\text { controls }]_{i t}+v_{i}+\varepsilon_{i t}
$$

In the baseline model (column 1 of Table 2), we regress the outcome against the two main treatment variables: negative $\left(T_{N E G}\right)$ and positive $\left(T_{P O S}\right)$ - with the constant term capturing the neutral treatment. In all the specifications, we control for the configuration of the income generation process. The coefficient associated to the real-effort dummy $\left(C_{R E}\right)$ is never statistically significant and always has a small size: we do not detect any systematic difference in tax compliance between subjects who earned their income performing the real-effort task and those who exogenously received their endowment in the form of windfall money ${ }^{6}$ (captured in the constant term of the regression). In more saturated models (columns 2-5) we also control for the amount of the individual income,

\footnotetext{
${ }^{6}$ This finding is in line with previous experimental evidence documented by Bühren and Kundt (2014) - comparing their endowed treatment vs. moderate-effort treatment.
} 
the fact of having received an audit in previous rounds, the fact of having being sanctioned, period dummies, idiosyncratic risk aversion, and an array of standard demographics (gender, age, field of studies, religious and political attitudes - see Table 2). In all models, the coefficient with the positive treatment turns out to be positive, sizable in its magnitude, and highly statistically significant. On average, subjects exposed to positive news reported a compliance rate of 23 percentage points ( $p$ value $<0.01)$ higher than those exposed to negative or neutral news. The compliance rate was negatively affected by both high levels of income and individual risk aversion.

Results do not change when we focus on the different factorial combinations by regressing tax compliance on the interaction between treatment dummies and the two income configurations (realeffort vs. windfall). As we show in Table 3 , both the factorial coefficients associated with the positive treatment $-T_{P O S}{ }^{*} C_{R E}$ and $T_{P O S}{ }^{*} C_{W F}$ - are statistically significant and sizable. Considering the encompassing model in column 5, participants exposed to the positive treatment who got their income through windfall money $T_{P O S}{ }^{*} C_{W F}$ exhibit a compliance rate of 22 percentage points ( $p$ value $<0.01$ ) higher than those exposed to neutral news who received a windfall income (reference cluster captured by the constant term). The size decreases to a still remarkable 17 percentage points $(p$-value $<0.05)$ for subjects exposed to the $T_{P O S}{ }^{*} C_{R E}$ condition (Wald test $p$-value $=0.07$ ) As anticipated by the result reported in Table 3, the coefficients of the two interactions based on the negative treatment turn out not to be statistically different from the constant term at any conventional level. The lack of any significant reaction of compliance to negative news once again supports the interpretation that participants perceive the media negativity bias as the norm rather than the exception, consistently with the prevailing view in the media negativity bias literature (Cappella and Jamieson, 1997; Garz 2014; Trussler and Soroka 2014; Soroka et al., 2018; Soroka et al., 2019).

\subsection{The magnitude of tax evasion}

The magnitude of tax evasion represents the intensive margin of tax compliance under the three main experimental treatments: negative, neutral, and positive. We measure the magnitude of tax evasion through a continuous index ranging between 0.001 and 1 in case of total evasion. As we are interested in the intensive margin, we focus only on non-compliers. By construction, this gradient 
Table 3: Tax compliance probability (extensive margin: $1=$ tax compliance; $0=$ tax evasion). Main experimental treatments: negative vs. positive.

\begin{tabular}{|c|c|c|c|c|c|}
\hline $\begin{array}{l}\text { Outcome: } \\
\text { tax compliance - } \\
\text { extensive margin }\end{array}$ & $\begin{array}{l}\text { Model } \\
\text { (1) }\end{array}$ & $\begin{array}{l}\text { Model } \\
(2)\end{array}$ & $\begin{array}{c}\text { Model } \\
(3)\end{array}$ & $\begin{array}{c}\text { Model } \\
(4)\end{array}$ & $\begin{array}{c}\text { Model } \\
(5)\end{array}$ \\
\hline$T_{N E G}$ & $\begin{array}{c}0.060 \\
(0.063)\end{array}$ & $\begin{array}{c}0.056 \\
(0.063)\end{array}$ & $\begin{array}{c}0.054 \\
(0.063)\end{array}$ & $\begin{array}{c}0.055 \\
(0.064)\end{array}$ & $\begin{array}{c}0.065 \\
(0.065)\end{array}$ \\
\hline$T_{P O S}$ & $\begin{array}{c}0.233^{* * *} \\
(0.063)\end{array}$ & $\begin{array}{c}0.233^{* * *} \\
(0.063)\end{array}$ & $\begin{array}{c}0.232^{* * *} \\
(0.063)\end{array}$ & $\begin{array}{c}0.233^{* * *} \\
(0.063)\end{array}$ & $\begin{array}{c}0.238^{* * *} \\
(0.065)\end{array}$ \\
\hline$C_{R E}$ & $\begin{array}{l}-0.025 \\
(0.051)\end{array}$ & $\begin{array}{l}-0.046 \\
(0.052)\end{array}$ & $\begin{array}{l}-0.054 \\
(0.052)\end{array}$ & $\begin{array}{l}-0.054 \\
(0.052)\end{array}$ & $\begin{array}{l}-0.059 \\
(0.052)\end{array}$ \\
\hline Income & & $\begin{array}{c}-0.001^{* * *} \\
(0.001)\end{array}$ & $\begin{array}{c}-0.001^{* * *} \\
(0.001)\end{array}$ & $\begin{array}{c}-0.001 * * * \\
(0.001)\end{array}$ & $\begin{array}{c}-0.001^{* * *} \\
(0.001)\end{array}$ \\
\hline Inspection lagged & & & & $\begin{array}{l}-0.033 \\
(0.092)\end{array}$ & $\begin{array}{l}-0.035 \\
(0.092)\end{array}$ \\
\hline Sanction lagged & & & & $\begin{array}{c}0.020 \\
(0.074)\end{array}$ & $\begin{array}{c}0.020 \\
(0.074)\end{array}$ \\
\hline Risk Aversion & & & & $\begin{array}{c}-0.442^{* * *} \\
(0.165)\end{array}$ & $\begin{array}{c}-0.403^{* *} \\
(0.168)\end{array}$ \\
\hline Round dummies & no & no & yes & yes & yes \\
\hline Demographics & no & no & no & no & yes \\
\hline $\begin{array}{l}\text { Constant } \\
T_{N E U}\end{array}$ & $\begin{array}{c}0.359^{* * *} \\
(0.055)\end{array}$ & $\begin{array}{c}0.525^{* * *} \\
(0.075)\end{array}$ & $\begin{array}{c}0.578^{* * *} \\
(0.086)\end{array}$ & $\begin{array}{c}0.579^{* * *} \\
(0.086)\end{array}$ & $\begin{array}{c}0.476 \\
(0.368)\end{array}$ \\
\hline$l l$ & -548.649 & -543.548 & -537.822 & -534.169 & -532.139 \\
\hline$p>\chi^{2}$ & 0.002 & 0.000 & 0.000 & 0.000 & 0.000 \\
\hline Obs. & 1,100 & 1,100 & 1,100 & 1,100 & 1,100 \\
\hline
\end{tabular}

Notes: Linear probability panel two-way model, with random effects - clusters: group, individual. Std. errors in parentheses, ${ }^{*} p<0.1{ }^{* *} p<0.05 ;{ }^{* * *} p<0.01$. 
Table 4: Tax compliance probability (extensive margin: $1=$ tax compliance; $0=$ tax evasion). Factorial interactions.

\begin{tabular}{|c|c|c|c|c|c|}
\hline $\begin{array}{l}\text { Outcome: } \\
\text { tax compliance - } \\
\text { extensive margin }\end{array}$ & $\begin{array}{l}\text { Model } \\
(1)\end{array}$ & $\begin{array}{l}\text { Model } \\
(2)\end{array}$ & $\begin{array}{l}\text { Model } \\
(3)\end{array}$ & $\begin{array}{c}\text { Model } \\
(4)\end{array}$ & $\begin{array}{c}\text { Model } \\
(5)\end{array}$ \\
\hline$T_{N E G}{ }^{*} C_{W F}$ & $\begin{array}{c}0.041 \\
(0.083)\end{array}$ & $\begin{array}{c}0.030 \\
(0.083)\end{array}$ & $\begin{array}{c}0.025 \\
(0.083)\end{array}$ & $\begin{array}{c}0.025 \\
(0.083)\end{array}$ & $\begin{array}{c}0.046 \\
(0.085)\end{array}$ \\
\hline$T_{N E G}{ }^{*} C_{R E}$ & $\begin{array}{c}0.036 \\
(0.081)\end{array}$ & $\begin{array}{c}0.016 \\
(0.081)\end{array}$ & $\begin{array}{c}0.007 \\
(0.081)\end{array}$ & $\begin{array}{c}0.007 \\
(0.081)\end{array}$ & $\begin{array}{c}0.013 \\
(0.083)\end{array}$ \\
\hline$T_{P O S}{ }^{*} C_{W F}$ & $\begin{array}{c}0.226^{* * *} \\
(0.083)\end{array}$ & $\begin{array}{c}0.227^{* * *} \\
(0.083)\end{array}$ & $\begin{array}{c}0.227^{* * *} \\
(0.083)\end{array}$ & $\begin{array}{c}0.228^{* * *} \\
(0.083)\end{array}$ & $\begin{array}{c}0.240^{* * * *} \\
(0.085)\end{array}$ \\
\hline$T_{P O S} * C_{R E}$ & $\begin{array}{c}0.199 * * \\
(0.079)\end{array}$ & $\begin{array}{c}0.173^{* *} \\
(0.079)\end{array}$ & $\begin{array}{c}0.163^{* *} \\
(0.080)\end{array}$ & $\begin{array}{c}0.163^{* *} \\
(0.080)\end{array}$ & $\begin{array}{c}0.168^{* *} \\
(0.081)\end{array}$ \\
\hline$T_{N E U^{*}} C_{R E}$ & $\begin{array}{c}0.036 \\
(0.081)\end{array}$ & $\begin{array}{c}0.016 \\
(0.081)\end{array}$ & $\begin{array}{c}0.007 \\
(0.081)\end{array}$ & $\begin{array}{c}0.007 \\
(0.081)\end{array}$ & $\begin{array}{c}0.013 \\
(0.083)\end{array}$ \\
\hline Income & & $\begin{array}{c}-0.001^{* * *} \\
(0.0001)\end{array}$ & $\begin{array}{c}-0.001^{* * *} \\
(0.0001)\end{array}$ & $\begin{array}{c}-0.001^{* * *} \\
(0.0001)\end{array}$ & $\begin{array}{c}-0.001^{* * *} \\
(0.0001)\end{array}$ \\
\hline Inspection lagged & & & & $\begin{array}{l}-0.033 \\
(0.092)\end{array}$ & $\begin{array}{l}-0.035 \\
(0.092)\end{array}$ \\
\hline Sanction lagged & & & & $\begin{array}{c}0.021 \\
(0.074)\end{array}$ & $\begin{array}{c}0.020 \\
(0.074)\end{array}$ \\
\hline Risk Aversion & & & & $\begin{array}{c}-0.457^{* * *} \\
(0.166)\end{array}$ & $\begin{array}{c}-0.418^{* *} \\
(0.169)\end{array}$ \\
\hline Round dummies & no & no & yes & yes & yes \\
\hline Demographics & no & no & no & no & yes \\
\hline $\begin{array}{l}\text { Constant } \\
T_{N E U^{*}} C_{W F}\end{array}$ & $\begin{array}{c}0.359^{* * *} * \\
(0.055)\end{array}$ & $\begin{array}{c}0.525^{* * *} \\
(0.075)\end{array}$ & $\begin{array}{c}0.578^{* * *} \\
(0.086)\end{array}$ & $\begin{array}{c}0.579^{* * *} \\
(0.086)\end{array}$ & $\begin{array}{c}0.476 \\
(0.368)\end{array}$ \\
\hline$l l$ & -548.586 & -543.4277 & -537.671 & -533.825 & -531.768 \\
\hline$p>\chi^{2}$ & 0.008 & 0.000 & 0.000 & 0.000 & 0.000 \\
\hline Obs. & 1,100 & 1,100 & 1,100 & 1,100 & 1,100 \\
\hline
\end{tabular}

Notes: Linear probability panel two-way model, with random effects - clusters: group, individual. Std. errors in parentheses, $* p<0.1 ; * * p<0.05 ; * * * p<0.01$. 
equals to 0 in case of full tax compliance. For this reason, subjects with an index equal to 0 are thus now not taken into consideration. As a result, the number of observations falls to 604. In Figure 2, we plot the average tax evasion rate observed under the three main treatment conditions. In all cases, the average value is around 0.6 (std. dev. 0.35), meaning that, on average, tax cheaters declared approximately 60 per cent of their actual income. Variations across treatments are negligible and not statistically robust.

Figure 2: Tax evasion intensity, by treatments.

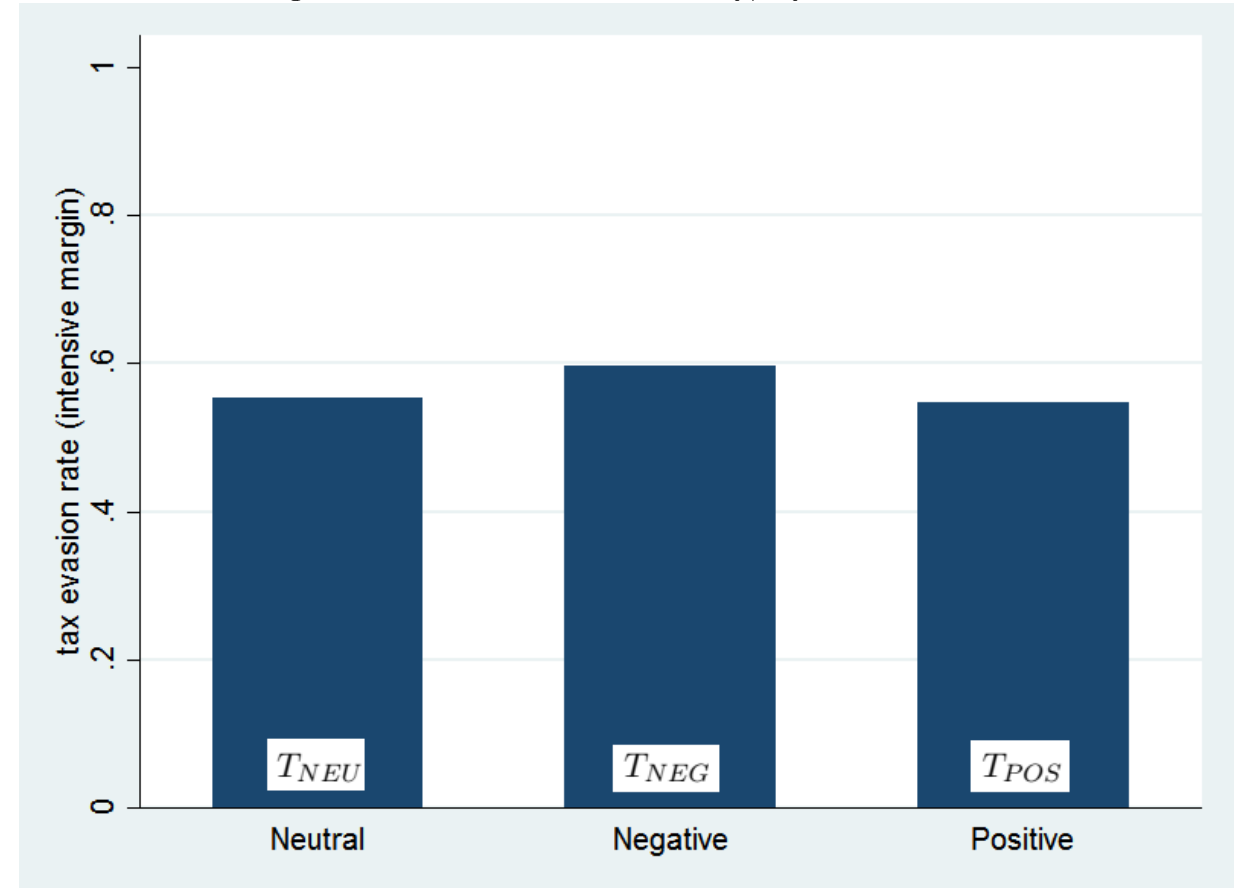

In Table 4, we report estimates from two-way panel models with random effects that account for potential individual dependencies over rounds and dependency within groups. In the baseline model (column 1), we regress the outcome against the two main treatment variables: negative $\left(T_{N E G}\right)$ and positive $\left(T_{P O S}\right)$ - with the constant term capturing the neutral treatment. We always control for the income of participants and the configuration under which they earned it $\left(C_{R E}\right.$ vs. $\left.C_{W F}\right)$, and in more saturated specifications we include the fact of having received an audit in previous rounds, the fact of having being sanctioned, period dummies, risk aversion, and the array of standard demographics. In all models, the main treatment coefficients (negative and positive) are small in size and never statistically significant at any conventional level. We detect no systematic difference in the intensity of tax evasion between the subjects who gained their income performing the real-effort task and 
those who received the endowment exogenously in the form of windfall money. The intensity of tax evasion was negatively associated with higher levels of income. Results do not change when we regress the outcome on the different factorial interactions between media bias treatments (negative, neutral, and positive) and the income configurations (real-effort vs. windfall). As Table 6 shows, no factorial interaction turns out to be economically meaningful and statistically significant at any conventional level.

\subsection{Double-Hurdle estimation}

Following recent inputs by Alm et al. (2017a) and Guerra and Harrington (2018) in the analysis of laboratory-generated data about the cultural determinants of tax evasion, we replicate the previous panel analyses adopting a Double-Hurdle (DH) approach. This class of models, introduced by Cragg (1971) and computationally developed by Engel and Moffatt (2014) for experimental applications, allow a combined estimation of the two distinct processes underlying the decision to comply and, for tax cheaters, the amount of the evasion (see Alm et al., 2017a section 5.2 and Guerra and Harrington, 2018 section 3.2). In this setup, the key outcome measure is always represented by the magnitude of tax evasion through a continuous index ranging between 0 in case of tax compliance and 1 in case of total tax evasion.

The first hurdle is interpretable as a probability model. It focuses on tax compliance and is particularly suited to capture the effect of media bias occurring at the extensive margin. The second hurdle, interpretable as a censored Tobit model, determines the gradient of tax evasion for those subjects who chose not to comply. It, therefore, captures the effect occurring at the intensive margin of tax evasion.

The series of Double-Hurdles models displayed in Table 7 well maps and combines the distinct results described in Table 3 and Table 5, H1 and H2 columns, respectively. Subjects exposed to the positive treatment are significantly less likely to engage in tax evasion (H1 columns). This effect is always highly statistically significant and sizable in its magnitude. The coefficient is quite stable across the various specifications characterized by different arrays of control variables. Results are also very consistent with the previous analysis as far as it concerns the intensive margin of tax evasion. We do not detect any significant differential treatment effect on the tax evasion intensive margin 
Table 5: Tax evasion intensity (intensive margin index: share of individual tax evasion, ranging from 0.001 to 1 ). Main experimental treatments: negative vs. positive.

\begin{tabular}{|c|c|c|c|c|c|}
\hline $\begin{array}{l}\text { Outcome: } \\
\text { tax evasion - } \\
\text { intensive margin }\end{array}$ & $\begin{array}{l}\text { Model } \\
(1)\end{array}$ & $\begin{array}{l}\text { Model } \\
(2)\end{array}$ & $\begin{array}{l}\text { Model } \\
(3)\end{array}$ & $\begin{array}{l}\text { Model } \\
(4)\end{array}$ & $\begin{array}{l}\text { Model } \\
(5)\end{array}$ \\
\hline$T_{N E G}$ & $\begin{array}{c}0.041 \\
(0.057)\end{array}$ & $\begin{array}{c}0.037 \\
(0.057)\end{array}$ & $\begin{array}{c}0.037 \\
(0.057)\end{array}$ & $\begin{array}{c}0.038 \\
(0.056)\end{array}$ & $\begin{array}{c}0.051 \\
(0.057)\end{array}$ \\
\hline$T_{P O S}$ & $\begin{array}{c}0.013 \\
(0.060)\end{array}$ & $\begin{array}{c}0.010 \\
(0.059)\end{array}$ & $\begin{array}{c}0.009 \\
(0.059)\end{array}$ & $\begin{array}{c}0.012 \\
(0.059)\end{array}$ & $\begin{array}{c}0.021 \\
(0.060)\end{array}$ \\
\hline$C_{R E}$ & $\begin{array}{l}-0.024 \\
(0.048)\end{array}$ & $\begin{array}{l}-0.038 \\
(0.048)\end{array}$ & $\begin{array}{l}-0.035 \\
(0.048)\end{array}$ & $\begin{array}{l}-0.036 \\
(0.048)\end{array}$ & $\begin{array}{l}-0.023 \\
(0.048)\end{array}$ \\
\hline Income & & $\begin{array}{c}-0.001^{* * *} \\
(0.0001)\end{array}$ & $\begin{array}{c}-0.001^{* * *} \\
(0.0001)\end{array}$ & $\begin{array}{c}-0.001 * * * \\
(0.0001)\end{array}$ & $\begin{array}{c}-0.001^{* * *} \\
(0.0001)\end{array}$ \\
\hline Inspection lagged & & & & $\begin{array}{l}-0.119 \\
(0.179)\end{array}$ & $\begin{array}{l}-0.076 \\
(0.177)\end{array}$ \\
\hline Sanction lagged & & & & $\begin{array}{c}0.054 \\
(0.052)\end{array}$ & $\begin{array}{c}0.051 \\
(0.052)\end{array}$ \\
\hline Risk Aversion & & & & $\begin{array}{l}-0.004 \\
(0.156)\end{array}$ & $\begin{array}{l}-0.103 \\
(0.157)\end{array}$ \\
\hline Round dummies & no & no & yes & yes & yes \\
\hline Demographics & no & no & no & no & yes \\
\hline $\begin{array}{l}\text { Constant } \\
T_{N E U}\end{array}$ & $\begin{array}{c}0.546^{* * *} \\
(0.043)\end{array}$ & $\begin{array}{c}0.673^{* * *} \\
(0.063)\end{array}$ & $\begin{array}{c}0.645^{* * *} \\
(0.073)\end{array}$ & $\begin{array}{c}0.649^{* * *} \\
(0.073)\end{array}$ & $\begin{array}{c}0.242 \\
(0.337)\end{array}$ \\
\hline$l l$ & -60.873 & -57.171 & -56.012 & -55.248 & -49.946 \\
\hline$p>\chi^{2}$ & 0.869 & 0.085 & 0.229 & 0.357 & 0.110 \\
\hline Obs. & 604 & 604 & 604 & 604 & 604 \\
\hline
\end{tabular}

Notes: Linear probability panel two-way model, with random effects - clusters: group, individual. Std. errors in parentheses, ${ }^{*} p<0.1{ }^{* *} p<0.05 ;^{* * *} p<0.01$. 
Table 6: Tax evasion intensity (intensive margin index: share of individual tax evasion, ranging from 0.01 to 1.00$)$. Full factorial design.

\begin{tabular}{|c|c|c|c|c|c|}
\hline $\begin{array}{l}\text { Outcome: } \\
\text { tax evasion - } \\
\text { intensive margin }\end{array}$ & $\begin{array}{l}\text { Model } \\
\text { (1) }\end{array}$ & $\begin{array}{l}\text { Model } \\
(2)\end{array}$ & $\begin{array}{l}\text { Model } \\
(3)\end{array}$ & $\begin{array}{c}\text { Model } \\
(4)\end{array}$ & $\begin{array}{l}\text { Model } \\
\quad(5)\end{array}$ \\
\hline$T_{N E G}{ }^{*} C_{W F}$ & $\begin{array}{c}0.056 \\
(0.076)\end{array}$ & $\begin{array}{c}0.047 \\
(0.076)\end{array}$ & $\begin{array}{c}0.046 \\
(0.076)\end{array}$ & $\begin{array}{c}0.046 \\
(0.076)\end{array}$ & $\begin{array}{c}0.056 \\
(0.076)\end{array}$ \\
\hline$T_{N E G}{ }^{*} C_{R E}$ & $\begin{array}{l}-0.017 \\
(0.084)\end{array}$ & $\begin{array}{l}-0.018 \\
(0.083)\end{array}$ & $\begin{array}{l}-0.020 \\
(0.083)\end{array}$ & $\begin{array}{l}-0.015 \\
(0.083)\end{array}$ & $\begin{array}{l}-0.006 \\
(0.083)\end{array}$ \\
\hline$T_{P O S}{ }^{*} C_{W F}$ & $\begin{array}{l}-0.031 \\
(0.084)\end{array}$ & $\begin{array}{c}-0.048 \\
(0.083)\end{array}$ & $\begin{array}{c}-0.046 \\
(0.083)\end{array}$ & $\begin{array}{c}-0.046 \\
(0.083)\end{array}$ & $\begin{array}{c}-0.035 \\
(0.081)\end{array}$ \\
\hline$T_{P O S}{ }^{*} C_{R E}$ & $\begin{array}{l}-0.001 \\
(0.073)\end{array}$ & $\begin{array}{l}-0.015 \\
(0.073)\end{array}$ & $\begin{array}{l}-0.013 \\
(0.073)\end{array}$ & $\begin{array}{l}-0.011 \\
(0.073)\end{array}$ & $\begin{array}{c}0.014 \\
(0.072)\end{array}$ \\
\hline$T_{N E U^{*}} C_{R E}$ & $\begin{array}{c}0.005 \\
(0.074)\end{array}$ & $\begin{array}{l}-0.015 \\
(0.074)\end{array}$ & $\begin{array}{l}-0.013 \\
(0.074)\end{array}$ & $\begin{array}{l}-0.012 \\
(0.074)\end{array}$ & $\begin{array}{c}0.009 \\
(0.073)\end{array}$ \\
\hline Income & & $\begin{array}{c}-0.001^{* * *} \\
(0.0001)\end{array}$ & $\begin{array}{c}-0.001^{* * *} \\
(0.0001)\end{array}$ & $\begin{array}{c}-0.001^{* * *} \\
(0.0001)\end{array}$ & $\begin{array}{c}-0.001^{* * *} \\
(0.0001)\end{array}$ \\
\hline Inspection lagged & & & & $\begin{array}{l}-0.112 \\
(0.179)\end{array}$ & $\begin{array}{l}-0.070 \\
(0.177)\end{array}$ \\
\hline Sanction lagged & & & & $\begin{array}{c}0.054 \\
(0.052)\end{array}$ & $\begin{array}{c}0.051 \\
(0.052)\end{array}$ \\
\hline Risk Aversion & & & & $\begin{array}{c}-0.012 \\
(0.158)\end{array}$ & $\begin{array}{l}-0.120 \\
(0.159)\end{array}$ \\
\hline Round dummies & no & no & yes & yes & yes \\
\hline Demographics & no & no & no & no & yes \\
\hline $\begin{array}{l}\text { Constant } \\
\left(T_{N E U}\right)\end{array}$ & $\begin{array}{c}0.548^{* * *} \\
(0.049)\end{array}$ & $\begin{array}{c}0.676^{* * *} \\
(0.068)\end{array}$ & $\begin{array}{c}0.647^{* * *} * \\
(0.078)\end{array}$ & $\begin{array}{c}0.651^{* * *} \\
(0.077)\end{array}$ & $\begin{array}{c}0.254 \\
(0.338)\end{array}$ \\
\hline$l l$ & -60.644 & -57.007 & -55.841 & -55.103 & -49.683 \\
\hline$p>\chi^{2}$ & 0.946 & 0.203 & 0.367 & 0.496 & 0.166 \\
\hline Obs. & 604 & 604 & 604 & 604 & 604 \\
\hline
\end{tabular}

Notes: Linear probability panel two-way model, with random effects - clusters: group, individual.

Std. errors in parentheses, ${ }^{*} p<0.1 ; * * p<0.05 ;{ }^{* * *} p<0.01$. 
captured on the second hurdle (H2 columns). Tax noncompliance (H1) is positively associated with income, while the intensity of tax evasion (H2) decreases with participants' earnings.

The general result picture does not change when we regress the outcome on the different factorial interactions between media bias treatments (negative, neutral, and positive) and the income configurations (real-effort vs. windfall). Focusing on the first hurdle (H1 columns) reported in Table 8, both the factorial coefficients associated with the positive treatment $-T_{P O S}{ }^{*} C_{R E}$ and $T_{P O S}{ }^{*} C_{W F}$ - are always statistically significant and stable in their magnitudes throughout the different specifications (1 to 5$)$. On the other hand, the coefficients associated with the interactions based on the negative treatment turn out not to be systematically different from the constant term. Results are also very consistent with the previous analysis regarding the intensive margin (H2 columns) of tax cheating behavior. In all the second hurdle models, no factorial interaction turns out to be economically meaningful and statistically significant at any conventional level.

\section{Discussion}

Our study provides the first experimental evidence that biased information about government action and public finance affects tax compliance, suggesting that news headlines act as a constant source of psychological priming. In the experiment, priming participants with positive news induced a significant change in their probability to comply. The exposure to negative news, instead, failed to elicit a behavioral response. The lack of effect can be interpreted as a form of expectation matching (negative news on government spending is what taxpayers routinely expect to see on a television screen) or as a sort of immunization effect: people are so used to an unfavorable presentation of public finance and policy issues that they fatalistically take negative news about the public sector as business as usual. In either case participants seem to perceive the media negativity bias as the norm rather than the exception. This result is in full accordance with evidence that a negativity bias systematically pervades political (Kepplinger et al., 2012; Lengauer et al., 2012; Elejalde et al., 2018) and economic (Garz, 2014; Soroka et al., 2018) news making. This phenomenon is demand-driven, as it is likely a product of a human tendency to be more attentive to negative news content (Soroka et al., 2019), and generates a sort of 'spiral of cynicism' (Cappella and Jamieson, 1997), in that the public's demand for sensational news strengthens the incentive for providing negative contents 


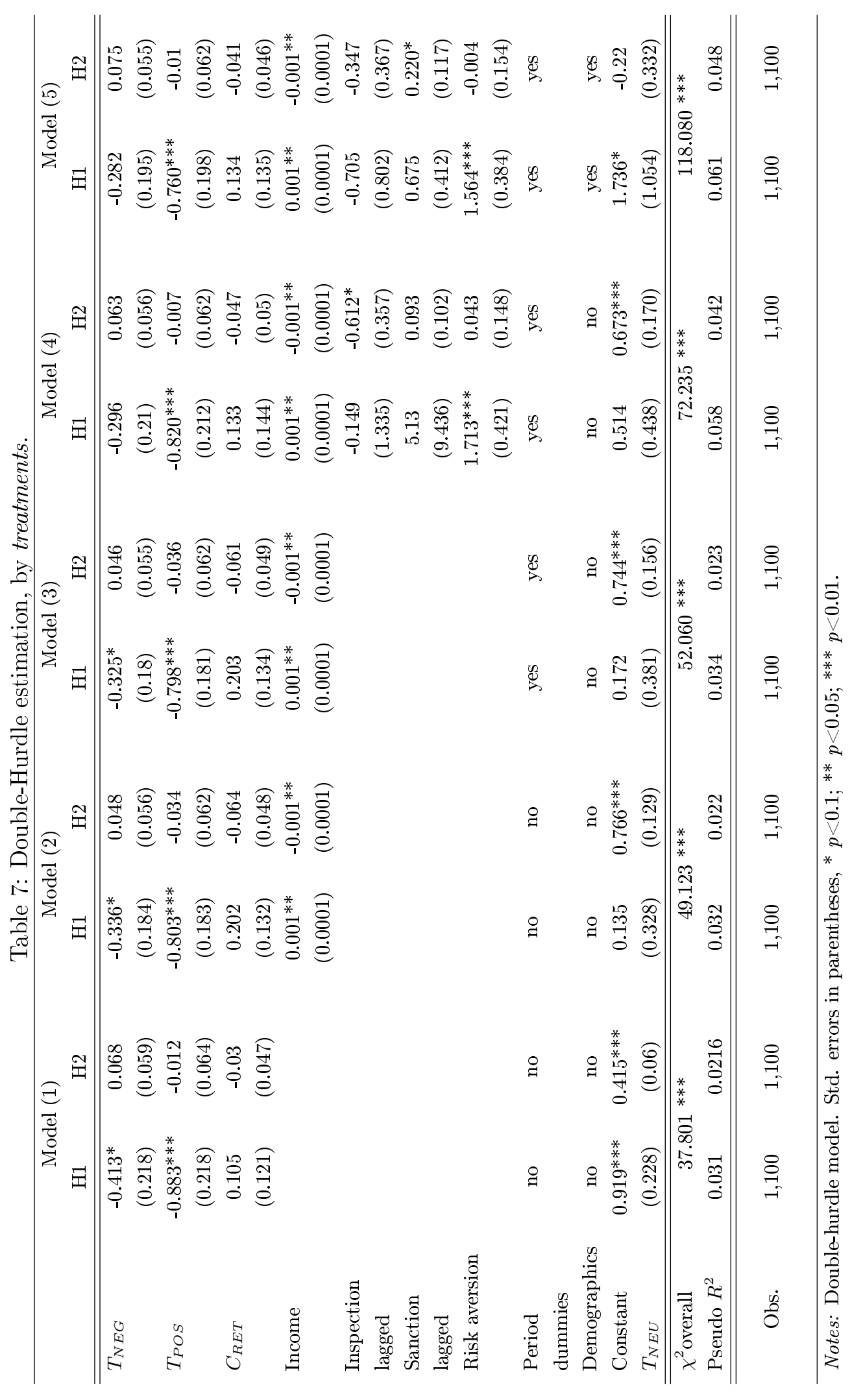




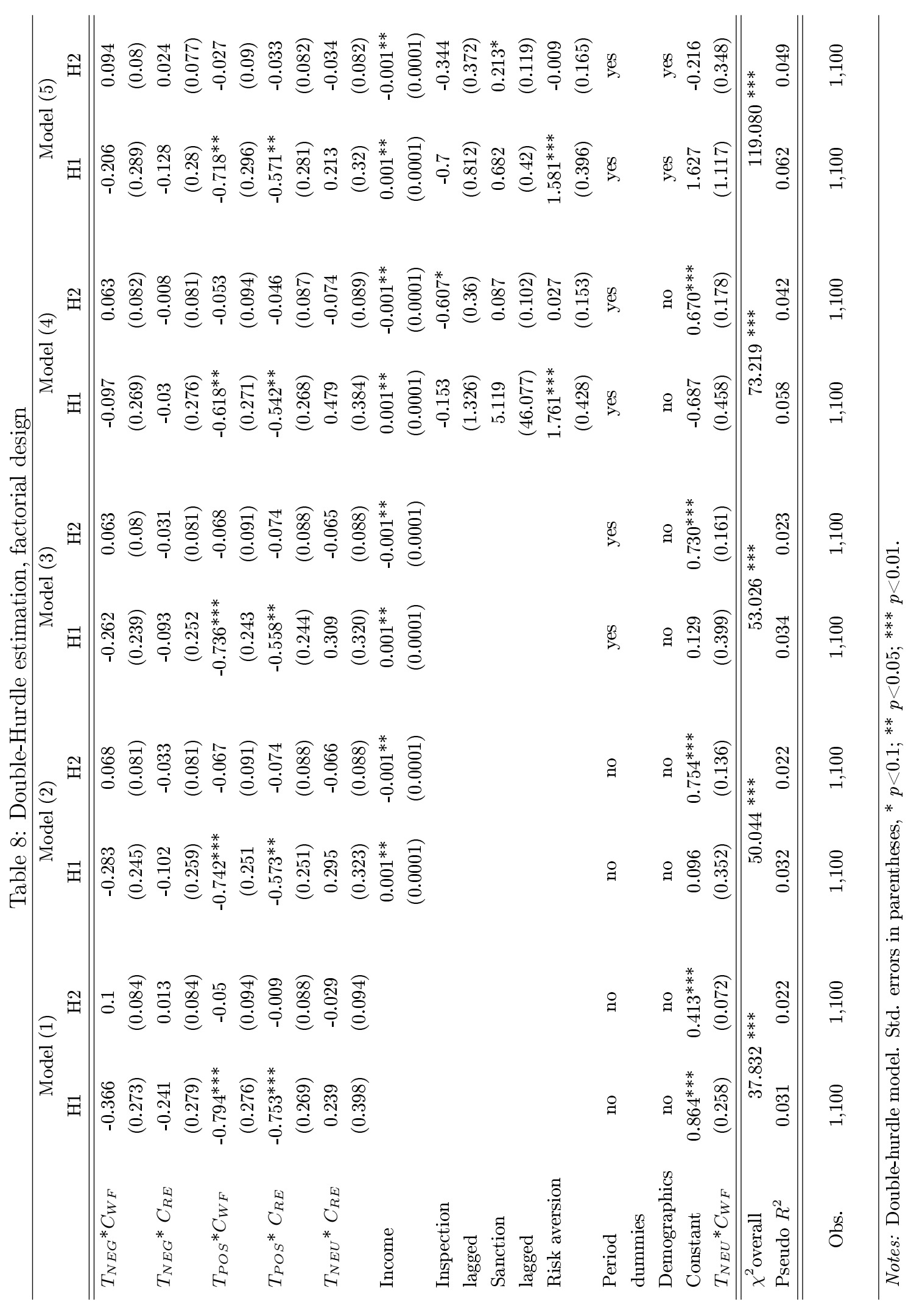


in journalists and newsmakers (Soroka et al., 2019). The recent spreading of anti-establishment narratives have further exacerbated the negativity bias in reporting about the efficiency and fairness of public institutions (Wettstein et al., 2018; Couttenier et al., 2019).

The analysis of the intensive margin of evasion also suggests that, once individuals have decided to cheat on taxes, media bias has no significant impact on the magnitude of tax evasion. It is in the first, and perhaps most important, stage of taxpayers' decision to comply that the bias of news about public finance and policy seems to play a crucial role.

These discouraging results, however, are balanced by the promising finding of the positive effect on tax compliance of even brief exposure to good news about the public sector's activity. Contrary to intuition, according to which a piece of adverse news is more salient than a good one, merely exposing participants with a few, authentic, information about the appropriate use of tax revenues acts as a powerful determinant of higher levels of tax compliance. This result is consistent with previous evidence that politeness in expressing a difference of opinions in social media is more salient than online incivility, and therefore prompts a stronger behavioral response across participants in a trust game (Antoci et al., 2019).

The effect of positive news is not only highly statistically significant and economically sizable but even robust to further manipulation in terms of whether participants earned their money based on a real-effort task or the exogenous decision of experimenters. This evidence indicates that the bias of information about public finance and policy matters more than the source of taxpayers' income.

From an economic perspective, the results of our experiment suggest that the satisfaction of taxpayers with the functioning of the public sector and the use of tax revenues is a critical driver of their compliance decisions. Citizens probably feel intrinsically motivated to honestly declare their full tax liability to the extent to which they perceive the outcomes of public policy as fair and legitimate, as if a sort of psychological contract with tax authorities was in force (Feld and Frey, 2007). The belief that the government does not spend well citizens' taxes may encourage them to reciprocate by refusing to pay their full tax liability (Spicer and Lundstedt, 1976). If, instead, the belief prevails that the government uses its tax revenue to appropriately fund public goods and services, taxpayers will be more willing to comply (Alm et al., 1993), even if they do not personally receive a full public good equivalent of their payments (Frey and Feld, 2002; Frey et al., 2004; Feld and Frey, 2007). Theories of the psychological contract imply a crucial role for information about public policy. However, citizens' awareness of the efficiency and fairness of public institutions does not 
only depend on the government's ability to fairly and adequately communicate about its use of tax revenues. Rather, it basically relies on the media's presentation of the efficiency and fairness of public institutions. Freedom in the provision, selection, and tone of information about the government is a cornerstone of democracy, and we indeed do not advice any form of governmental interference with the media's freedom of expression and critique. Our results instead suggest that stronger attention to impartially reporting - also - good news (Iggers, 2018) may ultimately strengthen the psychological contract between taxpayers and the state by allowing the public sector to fully exploit its tax revenue potential, which could, in turn, be conducive to improvements in the provision of public goods and services.

\section{Conclusion}

In this paper, we designed a framed laboratory experiment to study how the media bias in reporting about public finance and policy issues affects tax compliance in a repeated taxation game. The striking result of our study is that even minimal exposure to authentic news about the appropriate use of tax revenues by the public sector has a statistically significant and economically sizable effect on the probability to comply. This result suggests that what is at stake in taxpayers' reporting decisions may not be merely the rational choice between risky assets in a portfolio under the constraint of the tax audits and penalties. Individuals may tend to reciprocate the behavior they observe in the government, and more in general in public institutions, as if they were bounded to them by a psychological contract (Frey and Feld, 2002; Feld and Frey, 2007). If citizens believe the government is pursuing its objectives with efficiency and fairness, they may be more intrinsically motivated to pay their taxes to contribute to the welfare of the community. Theories of the psychological contract do not explicitly point out the crucial role of communication and information in nudging taxpayers' behavioral responses based on reciprocity. In our experiment, we highlighted and clarified this role. Overall, our results reveal that biased news function as a constant source of psychological priming influencing tax compliance decisions. The systematic tendency of the media to focus on negative news entails hidden social costs related to the government's inability to fully exploit its tax revenue potential and meet its fiscal goals, with detrimental effects on the efficient provision of public goods and services.

The take-home message for policymakers is rather straightforward. Public policy can create the 
preconditions to promote tax compliance in previously unsuspected ways. The design of strategies and incentives nudging the provision of more balanced information that impartially reports also positive news (Iggers, 2018) could help the government to meet its tax revenue objectives, possibly feeding a virtuous cycle through the more efficient provision of public goods and services. In doing so, the preservation of freedom of expression and critique would play a crucial role not only in supporting democracy but also in strengthening the belief that the political process is fair and the policy outcomes legitimate, which could, in turn, further underpin tax morale and compliance. 


\section{References}

Abeler, J., Falk, A., Goette, L., and Huffman, D. (2011). Reference points and effort provision. American Economic Review, 101(2):470-92.

Agridas, C. (2015). What drives media bias? new evidence from recent newspaper closures. Journal of Media Economics, 28(3):123-141.

Alesina, A. and Angeletos, G. M. (2005). Fairness and redistribution. American Economic Review, 95(4):960-980.

Allingham, M. G. and Sandmmo, A. (1992). Income and tax evasion: a theoretical analysis. Journal of Public Economics, 1(3-4):323-338.

Alm, J. (2019). What motivates tax compliance? Journal of Economic Surveys, 33(2):353-388.

Alm, J., Bernasconi, M., Laury, S., Lee, D. J., and Wallace, S. (2017a). Culture, compliance, and confidentiality: Taxpayer behavior in the united states and italy. Journal of Economic Behavior and Organization, 140:176-196.

Alm, J., Bloomquist, K. M., and McKee, M. (2015). On the external validity of laboratory tax compliance experiments. Economic Inquiry, 53(2):1170-1186.

Alm, J., Bloomquist, K. M., and McKee, M. (2017b). When you know your neighbour pays taxes: Information, peer effects and tax compliance. Fiscal Studies, 38:587-613.

Alm, J., Jackson, B. R., and McKee, M. (1993). Fiscal exchange, collective decision institutions, and tax compliance. Journal of Economic Behavior and Organization, 22(3):285-303.

Alm, J., Malezieux, A., and McKee, M. (2019). 40 years of tax evasion games: A meta-analysis. Technical report, Mimeo.

Alm, J., Martinez-Vazquez, J., and McClellan, C. (2016). Corruption and firm tax evasion. Journal of Economic Behavior and Organization, 124:146-163.

Andreoni, J., Erard, B., and Feinstein, J. (1998). Tax compliance. Journal of Economic Literature, $36(2): 818-860$.

Antoci, A., Bonelli, L., Paglieri, F., Reggiani, T., and Sabatini, F. (2019). Civility and trust in social media. Journal of Economic Behavior and Organization, 160:83-99.

Attanasi, G., Georgantzís, N., Rotondi, V., and Vigani, D. (2018). Lottery-and survey-based risk attitudes linked through a multichoice elicitation task. Theory and Decision, 84(3):341-372.

Becker, G. S. (1968). Crime and punishment: an economic approach. Journal of Political Economy, $76: 169-217$.

Benesch, C., Loretz, S., Stadelmann, D., and Thomas, T. (2019). Media coverage and immigration worries: Econometric evidence. Journal of Economic Behavior and Organization, 160:52-67.

Bock, O., Baetge, I., and Nicklish, A. (2014). Hroot: Hamburg registration and organization online tool. European Economic Review, 71:117-120.

Bühren, C. and Kundt, T. C. (2014). Does the level of work effort influence tax evasion? experimental evidence. Review of Economics, 65(2):137-158. 
Calvet Christian, R. and Alm, J. (2014). Empathy, sympathy, and tax compliance. Journal of Economic Psychology, 40(C):62-82.

Cappella, J. N. and Jamieson, K. H. (1997). Spiral of cynicism: The press and the public good. Oxford University Press, Oxford.

Casal, S. and Mittone, L. (2016). Social esteem versus social stigma: The role of anonymity in an income reporting game. Journal of Economic Behavior \& Organization, 124:55-66.

Cerqueti, R., Sabatini, F., and Ventura, M. (2019). Civic capital and support for the welfare state. Social Choice and Welfare, 53(2):313-336.

Charness, G. and Villeval, M.-C. (2009). Cooperation and competition in intergenerational experiments in the field and the laboratory. American Economic Review, 99(3):956-78.

Chiang, C. F. and Knight, B. (2011). Media bias and influence: Evidence from newspaper endorsements. Review of Economic Studies, 78(3):795-820.

Chiapello, M. (2018). Balancetable: Stata module to build a balance table. Technical report, Boston College - Department of Economics.

Clark, J. (2002). House money effects in public good experiments. Experimental Economics, $5(3): 223-231$.

Corazzini, L., Cotton, C., and Reggiani, T. (2019). Delegation and coordination with multiple threshold public goods: experimental evidence. Experimental Economics, pages 1-39.

Corazzini, L., Cotton, C., and Valbonesi, P. (2015). Donor coordination in project funding: Evidence from a treshold public goods experiment. Journal of Public Economics, 128:16-29.

Couttenier, M., Hatte, S., Thoenig, M., and Vlachos, S. (2019). The logic of fear - populism and media coverage of immigrant crimes. CEPR Discussion Paper DP13496.

Cragg, J. G. (1971). Some statistical models for limited dependent variables with application to the demand for durable goods. Econometrica (pre-1986), 39(5):829.

Della Vigna, S. and Kaplan, E. (2007). The fox news effect: media bias and voting. Quarterly Journal of Economics, 122(3):1187-1234.

Durante, R. and Knight, B. (2012). Partisan control, media bias, and viewer responses: evidence from berlusconi's italy. Journal of the European Economic Association, 10(3):451-481.

Durante, R., Pinotti, P., and Tesei, A. (2019). The political legacy of entertainment tv. American Economic Review, 109(7):2497-2530.

Durham, Y., Manly, T. S., and Ritsema, C. (2014). The effects of income source, context, and income level on tax compliance decisions in a dynamic experiment. Journal of Economic Psychology, 40:220-233.

Dwenger, N., Kleven, H., and Rasul, I. amnd Rincke, J. (2016). Extrinsic and intrinsic motivations for tax compliance: evidence from a field experiment in germany. American Economic Journal: Economic Policy, 8(3):203-232.

Elejalde, E., Ferres, L., and Herder, E. (2018). On the nature of real and perceived bias in the mainstream media. PLoS ONE, https://doi.org/10.1371/journal.pone.0193765. 
Engel, C. and Moffatt, P. G. (2014). dhreg, xtdhreg, and bootdhreg: Commands to implement double-hurdle regression. The Stata Journal, 14(4):778-797.

Feld, L. and Frey, B. (2007). Tax compliance as the result of a psychological tax contract: The role of incentives and responsive regulation. Law and Policy, 29(1):102-120.

Fischbacher, U. (2007). Z-tree: Zurich toolbox for ready-made economic experiments. Experimental Economics, 10(2):171-178.

Frey, B., Benz, M., and Stutzer, A. (2004). Introducing procedural utility: not only what but also how matters. Journal of Theoretical and Institutional Economics, 160:377-401.

Frey, B. and Feld, L. (2002). Deterrence and morale in taxation: an empirical analysis. Cesifo Working Paper no. 760.

Garz, M. (2014). Good news and bad news: evidence of media bias in unemployment reports. Public Choice, 161(3-4):499-515.

Gërxhani, K. and Schram, A. (2006). Tax evasion and income source: A comparative experimental study. Journal of Economic Psychology, 27(3):402-422.

Gobena, L. B. and van Dijke, M. (2017). Fear and caring: Procedural justice, trust, and collective identification as antecedents of voluntary tax compliance. Journal of Economic Psychology, 62:116 .

Gualtieri, G., Nicolini, M., and Sabatini, F. (2019). Repeated shocks and preferences for redistribution. Journal of Economic Behavior and Organization, 167:53-71.

Guerra, A. and Harrington, B. (2018). Attitude-behavior consistency in tax compliance: A crossnational comparison. Journal of Economic Behavior and Organization, 156:184-205.

Harrison, G. and List, J. (2004). Field experiments. Journal of Economic Literature, 42(4):10091055 .

Hartner, M., Rechberger, S., Kirchler, E., and Schabmann, A. (2008). Procedural fairness and tax compliance. Economic Analysis and Policy, 38(1):137-152.

Iggers, J. (2018). Good news, bad news: Journalism ethics and the public interest. Routledge.

Kepplinger, H. M., Geiss, S., and Siebert, S. (2012). Framing scandals: Cognitive and emotional media effects. Journal of Communication, 62(4):659-681.

Koessler, A.-K., Torgler, B., Feld, L. P., and Frey, B. S. (2019). Commitment to pay taxes: Results from field and laboratory experiments. European Economic Review, 115:78-98.

Kogler, C., Mittone, L., and Kirchler, E. (2016). Delayed feedback on tax audits affects compliance and fairness perceptions. Journal of Economic Behavior and Organization, 124:81-87.

Le Moglie, M. and Turati, G. (2019). Electoral cycle bias in the media coverage of corruption news. Journal of Economic Behavior and Organization, 163:140-157.

Lengauer, G., Esser, F., and Berganza, R. (2012). Negativity in political news: A review of concepts, operationalizations and key findings. Journalism, 13:179-202.

Luttmer, E. F. P. and Singhal, M. (2011). Culture, context and the taste for redistribution. American Economic Journal: Economic Policy, 3:157-179. 
Luttmer, E. F. P. and Singhal, M. (2014). Tax morale. Journal of Economic Perspectives, 28:149168.

Malezieux, A. (2018). A practical guide to setting up your tax evasion game. Journal of Tax Administration, 4(1):107-127.

Mastrorocco, N. and Minale, L. (2018). News media and crime perceptions: Evidence from a natural experiment. Journal of Public Economics, 165:230-255.

Mazar, N., Amir, O., and Ariely, D. (2008). The dishonesty of honest people: A theory of self-concept maintenance. Journal of marketing research, 45(6):633-644.

Murphy, K. and Tyler, T. (2008). Procedural justice and compliance behavior. European Journal of Social Psychology, 38(4):652-668.

Nguyen, V. H. and Claus, E. (2013). Good news, bad news, consumer sentiment and consumption behavior. Journal of Economic Psychology, 39:426-438.

Sabatini, F., Ventura, M., Yamamura, E., and Zamparelli, L. (2020). Fairness and the unselfish demand for redistribution by taxpayers and welfare recipients. Southern Economic Journal, $86(3): 971-988$.

Scarpina, F. and Tagini, S. (2017). The stroop color and word test. Frontiers in psychology, 8:557.

Smith, K. W. (1992). Reciprocity and fairness: positive incentives for tax compliance. In Why people pay taxes: tax compliance and enforcement. University of Michigan Press, Ann Arbor.

Soroka, S., Daku, M. amd Hiaeshutter-Rice, D., Guggenheim, L., and Pasek, J. (2018). Negativity and positivity biases in economic news coverage: Traditional versus social media. Communication Research, 45(7):1078-1098.

Soroka, S., Fournier, P., and Nir, L. (2019). Cross-national evidence of a negativity bias in psychophysiological reactions to news. Proceedings of the National Academy of Science, 116(38):https://doi.org/10.1073/pnas.1908369116.

Spicer, M. W. and Lundstedt, S. B. (1976). Understanding tax evasion. Public Finance, 31(2):295305.

Taboada, M., Brooke, J., Tofiloski, M., Voll, K., and Stede, M. (2011). Lexicon-based methods for sentiment analysis. Computational Linguistics, 37(2):267-307.

Torgler, B. (2006). The importance of faith: Tax morale and religiosity. Journal of Economic Behavior and Organization, 61(1):81-109.

Trussler, M. and Soroka, S. (2014). Consumer demand for cynical and negative news frames. International Journal of Press/Politics, 19(3):360-379.

Tyler, T. R. (1990). Why people obey the law. Yale University Press, New Haven, Connecticut.

van Dijke, M. and Verboon, P. (2010). Trust in authorities as a boundary condition to procedural fairness effects on tax compliance. Journal of Economic Psychology, 31(1):80-91.

Wettstein, M., Esser, F., Schulz, A., Wirz, D. S., and Wirth, W. (2018). News media as gatekeepers, critics, and initiators of populist communication: How journalists in ten countries deal with the populist challenge. International Journal of Press/Politics, 23(4):476-495. 


\section{Appendix}

\section{[A] Headline news:}

\section{i) Negative treatment $\left(T_{N E G}\right)$}

- National debt increased to CZK 1.68 billion.

- Each Czech citizen owes CZK 160,000.

- Bill for 2013: Czech Railways exceeded budget by CZK 2 billion.

- Public employment service in chaos. Disbursement of benefits not working.

- Low civil servant efficiency decreased the Czech Republic's competitiveness; down to 46th in global ranking.

- Due to illegal acquisition of locomotives, Czech Railways to pay a fine of CZK 25 million.

- Proposed budget criticized: Government not saving, only choking off investments.

- Eurovia could get a 72 million contract from the ministry without a tender.

- The public sector is being unscrupulously milked, warns SIS. Leopold Cerný: ProMoPro is a textbook example of tunneling with the state's assistance.

- Water leaking into Blanka tunnel. Grand opening in December jeopardized.

- Tenders organized by entrepreneurs themselves; civil servants just observers.

- Deputies met for only hours and three-quarters did not attend the meeting.

- Overpriced hospital equipment means the Czech Republic to return CZK 163 million to the EU.

- Ministry of Defense declassified an audit revealing overpriced warehouse security.

- Reconstruction of D1 at Velká Bíteš may be delayed up to year, says head of RSD.

ii) Positive treatment $\left(T_{P O S}\right)$

- South Bohemian Hospitals achieved efficient operations.

- Investment of CZK 818 million brings increased comfort and modern medical technologies to patients in Czech hospitals.

- Governmental program supporting science centers and generous grants successful: Best minds returning home.

- Foreign experts confirm top-class research at CEITEC.

- State housing development fund can provide advantageous loans to renovate housing estates thanks to new CZK 600 million project.

- During Q1, public employment service financially supported retraining of 14173 job applicants. Unemployment rate fell by $1.3 \%$.

- During Q1, public employment service granted CZK 972 million to support employment of disabled. 
- Bikeway system to connect three regions in autumn with completion of construction in Zlín Region.

- Czech Republic's economy is the 26th freest - improvement of 3 places.

- State financing ground-breaking research on bowel cancer. New research center to be established in Prague.

- State agency CzechInvest successfully introduced several Czech startups in San Francisco.

- The campaign to attract tourists a success, says state agency CzechTourism. Year-on-year increase in foreign visitors to the Czech Republic 18.5

- Departments keeping operating costs low. This has decreased state budget deficit.

- Compensation paid out for delayed trains has fallen. Czech Railways trains running on schedule. 24

iii) Neutral treatment $\left(T_{N E U}\right)$

- The International Space Station could be replaced by a base on the Moon.

- Gray cars, unobtrusive star in sales. Popularity of white color begins to decline.

- Skier Strachova finished fifth in Flachau.

- Volkswagen Beetle celebrates 70 th anniversary.

- Car speed will not be measured in $\mathrm{km} / \mathrm{h}$ but in bit / $\mathrm{s}$.

- Activision Blizzard Studios will be led by Stacey Sher.

- Actor Javorský plays Burian, Novotný plays Marvan.

- An asteroid flew through the Solar system.

- The winner of the Grand Prix of Architects 2015 was the Cottage by the Lake by FAM Architekti.

- World dog show Crufts started.

- Fish oil, wine and swimming. Stašová revealed the secret of her figure.

- Hunters moved hare from a strictly guarded area of Temelín power plant.

- Magnesia Litera 2015: The book of the year is Poet Martin Reiner.

- Singer Hana Zagorova finally in the Hall of Fame!

- Tesla's first SUV has wings. Electricity will cover over 400 kilometers.

\section{[B] Online supplementary material:}

VIDEOS: http://bit.ly/388jDgL 


\section{MUNI Econ Working Paper Series (since 2018)}

2020-01 Fišar, M., Reggiani, T., Sabatini, F., Špalek, J. (2020). Media Bias and Tax Compliance: Experimental Evidence. MUNI ECON Working Paper n. 2020-01. Brno: Masaryk University. https://doi.org/10.5817/WP_MUNI_ECON_2020-01

2019-08 Fišar, M., Krčál, O., Špalek, J., Staněk, R., Tremewan, J. 2019. A Competitive Audit Selection Mechanism with Incomplete Information. MUNI ECON Working Paper n. 2019-08. Brno: Masaryk University. https://doi.org/10.5817/WP_MUNI_ECON_2019-08

2019-07 Guzi, M., Huber, P., Mikula, M. 2019. Old sins cast long shadows: The Long-term impact of the resettlement of the Sudetenland on residential migration. MUNI ECON Working Paper n. 2019-07. Brno: Masaryk University. https://doi.org/10.5817/WP_MUNI_ECON_2019-07

2019-06 Mikula, M., Montag, J. 2019. Does homeownership hinder labor market activity? Evidence from housing privatization and restitution in Brno. MUNI ECON Working Paper n. 2019-06. Brno: Masaryk University. https://doi.org/10.5817/WP_MUNI_ECON_2019-06

2019-05 Krčál, O., Staněk, R., Slanicay, M. 2019. Made for the job or by the job? A lab-in-the-field experiment with firefighters. MUNI ECON Working Paper n. 2019-05. Brno: Masaryk University. https://doi.org/10.5817/WP_MUNI_ECON_2019-05

2019-04 Bruni, L., Pelligra, V., Reggiani, T., Rizzolli, M. 2019. The Pied Piper: Prizes, Incentives, and Motivation Crowding-in. MUNI ECON Working Paper n. 2019-04. Brno: Masaryk University. https://doi.org/10.5817/WP_MUNI_ECON_2019-04

2019-03 Krčál, O., Staněk, R., Karlínová, B., Peer, S. 2019. Real consequences matters: why hypothetical biases in the valuation of time persist even in controlled lab experiments. MUNI ECON Working Paper n. 2019-03. Brno: Masaryk University. https://doi.org/10.5817/WP_MUNI_ECON_2019-03

2019-02 Corazzini, L., Cotton, C., Reggiani, T., 2019. Delegation And Coordination With Multiple Threshold Public Goods: Experimental Evidence. MUNI ECON Working Paper n. 2019-02. Brno: Masaryk University. https://doi.org/10.5817/WP_MUNI_ECON_2019-02

2019-01 Fišar, M., Krčál, O., Staněk, R., Špalek, J. 2019. The Effects of Staff-rotation in Public Administration on the Decision to Bribe or be Bribed. MUNI ECON Working Paper n. 2019-01. Brno: Masaryk University. https://doi.org/10.5817/WP_MUNI_ECON_2019-01

2018-02 Guzi, M., Kahanec, M. 2018. Income Inequality and the Size of Government: A Causal Analysis. MUNI ECON Working Paper n. 2018-02. Brno: Masaryk University. https://doi.org/10.5817/WP_MUNI_ECON_2018-02

2018-01 Geraci, A., Nardotto, M., Reggiani, T., Sabatini, F. 2018. Broadband Internet and Social Capital. MUNI ECON Working Paper n. 2018-01. Brno: Masaryk University. https://doi.org/10.5817/WP_MUNI_ECON_2018-01

ISSN electronic edition 2571-130X

MUNI ECON Working Paper Series is indexed in RePEc:

https://ideas.repec.org/s/mub/wpaper.html 